\title{
Sciendo
}

RESEARCH PAPERS FACULTY OF MATERIALS

SCIENCE AND TECHNOLOGY IN TRNAVA

SLOVAK UNIVERSITY OF TECHNOLOGY

IN BRATISLAVA

2018, Volume 26, Number 42

DOI 10.2478/rput-2018-0016

\section{EFFECTS OF LOGISTIC PROCESSES TO THE MAINTENANCE TIME}

\author{
Péter TELEK \\ UNIVERSITY OF MISKOLC \\ FACULTY OF MECHANICAL ENGINEERING AND INFORMATICS \\ INSTITUTE OF LOGISTICS \\ H-3515, MisKOLC-EGYETEMVÁROS, HUNGARY \\ e-mail: alttelek@uni-miskolc.hu \\ Received: 31.05.2018, Accepted: 28.06.2018, Published: 19.09.2018
}

\begin{abstract}
In these days, the maintenance process, as a part of the operation of manufacturing systems, is also developing while following the changes in the production area. Maintenance, in many of the cases, is operating as an individual service task, which requires many changes from the related handling processes. To follow the changes and the development in the field of the maintenance, we need many new concepts, methods and ideas. Main objective of our research was to uncover the relations between the effectivity of the maintenance processes and the material handling parameters. In this paper, we summarise the development of the maintenance processes and give an overview about the topical handling tasks, which must be solved.
\end{abstract}

\section{Key words}

Maintenance, time components, logistics process, efficiency

\section{INTRODUCTION}

Nowadays, the maintenance process, as a part of the operation of manufacturing systems, is also developing, following the changes in the production area. Maintenance, in many of the cases, is operating as an individual service task, which requires many changes from the related handling processes. To follow the changes and the development in the field of the maintenance, we need many new concepts, methods and ideas in all related areas.

Main objective of our research to uncover the relations between the effectivity of the maintenance processes and the material handling parameters. To reach our goal, we must analyse the maintenance systems and their handling requirements.

In this paper, we summarise the development of the maintenance processes and give an overview about the actual handling tasks, which must be solved. Beside it, we are focussing to the time-factors of the handling processes and try to find solutions to reduce their negative consequences. 


\section{ADVANCED MAINTENANCE PROCESSES}

Wear-and-tear of a technical equipment is a natural procedure, which causes different negative changings. To avoid the consequences, we must apply a suitable maintenance process, which involves the control, maintain and repair activities related to the given equipment (machines, devices, vehicles, etc.) (1).

Some decades ago, maintenance was a simple, internal task within the production hall, which was realized by a special group of the manufacturing team, settled close to the manufacturing machines. Size and location of the maintenance facilities were depending on the parameters of the given tasks and the production area. An important characterisation of the maintenance processes was the direct link to the production process, which significantly influenced its operation.

In the last quarter of the twentieth century, diagnostic methods appeared in the maintenance processes, which opened new directions in the control of the machines. Next step of the development was the Reliability Centred Maintenance (RCM), which based on the reliability of the machines and meant a new point-of-view, at first mainly in the aircraft production. The last concept is the Total Productive Maintenance (TPM), which - similarly to the Total Quality Management (TQM) systems - tries to give the responsibility for certain tasks of the maintenance (keeping, observing, etc.) to the handling operators to avoid malfunctions and crashes (2).

The new efficiency requirements of the economy and the industry significantly deformed the structure of the production and service processes. It is also true for the maintenance systems, where one of the most important changes is that the maintenance activities often made by service companies and the owners of the machines has no control on the processes. In many times, mainly at large, high productive equipment, the producers offer the maintenance for their machines as an additional service. Beside it, in many cases, the maintenance is much more effective, as a service, because of the specialization and the experience of the operators in numerous similar tasks. Another important changing is the developing of maintenance networks, which control special tasks (e. g. elevator maintenance) in large areas (3).

We can say, that the tasks and objectives of the maintenance is the same as in the last century, but the realization and organization of the tasks are significantly changed, which have important effects to the handling processes.

\section{MAINTENANCE LOGISTICS}

Most important task of the maintenance logistics is to take care about the materials, elements, devices and operators required by the maintenance processes, with the next activities:

- element supply,

- element and device storing,

- allocation of the operators,

- handling of elements, devices and operators,

- handling of the wastes related to the maintenance.

Changes in the maintenance processes result new ideas and advanced solutions within the logistic processes (4) and the maintenance service companies require more and better material handling devices and more effective design methods for the external transport and organization tasks (5) (Fig. 1). Important characterisation of the service companies is the 
application of parallel processes, which much more effective, but highly increases the complexity of the logistic system (6).

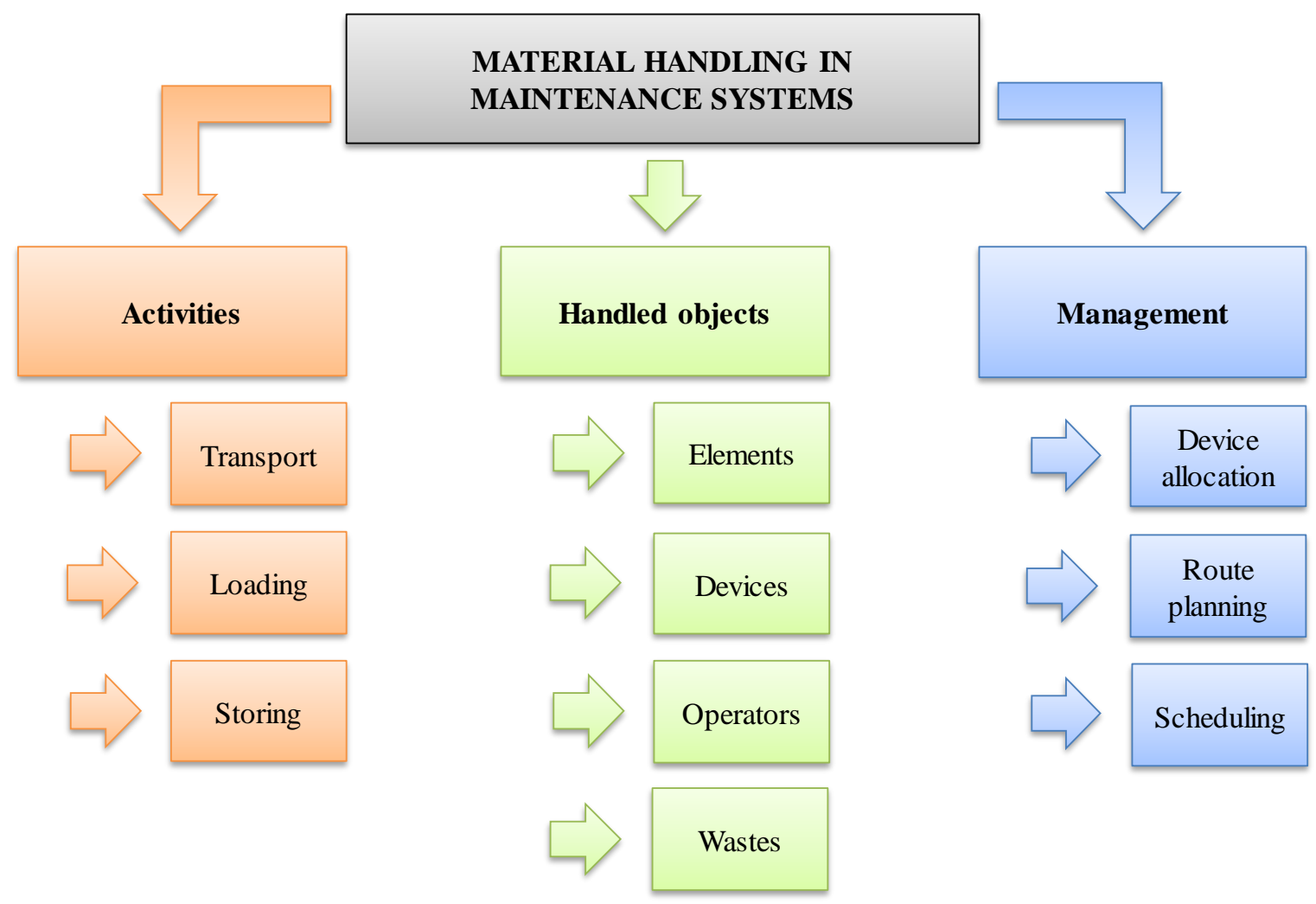

Fig. 1 Handling complexity of the maintenance processes

At maintenance networks, the logistic activities are more complex, than in the individual maintenance tasks, so their realization requires also complex methods and procedures (7). For example, to analyse the logistic parameters of an elevator maintenance network the application of high level optimization algorithm is required, because of the large number of objects and experts (8).

In generally, it can be observed that the maintenance process and its handling activities are separated (mainly in large systems) and sometimes the logistic activities belong to another service company. In special cases, the supplying and storing of the elements for the maintenance processes are organized by the owner of the machine, but the other logistic tasks (e. g. transport, loading) are operated by other logistic service company.

\section{TIME COMPONENTS OF MAINTENANCE PROCESSES}

In advanced manufacturing systems, the productivity is usually high, so the effects of the maintenance processes can be very large in time and cost. To control the maintenance processes, we need different parameters to evaluate the performance and effectivity of the activities. As the maintenance is a kind of service, so their parameters cannot be measured directly. In this aspect, the most important parameters are the error-free operation and the time-requirement of the maintenance activities.

Maintenance processes have given time requirement, which usually reduces the useful operation time of the machines. This time requirement consists of different time-components, which have individual effects to the processes. Influencing these components gives possibility 
to increase the effectivity of the maintenance process and reduce the losses caused by their activities.

The time-loss in the operation of the maintained machine is not the same as the timerequirement (Fig. 2), but they have closed relations. There is no time-loss if the maintenance activities are performed in passive state of the machine (when it is not working).

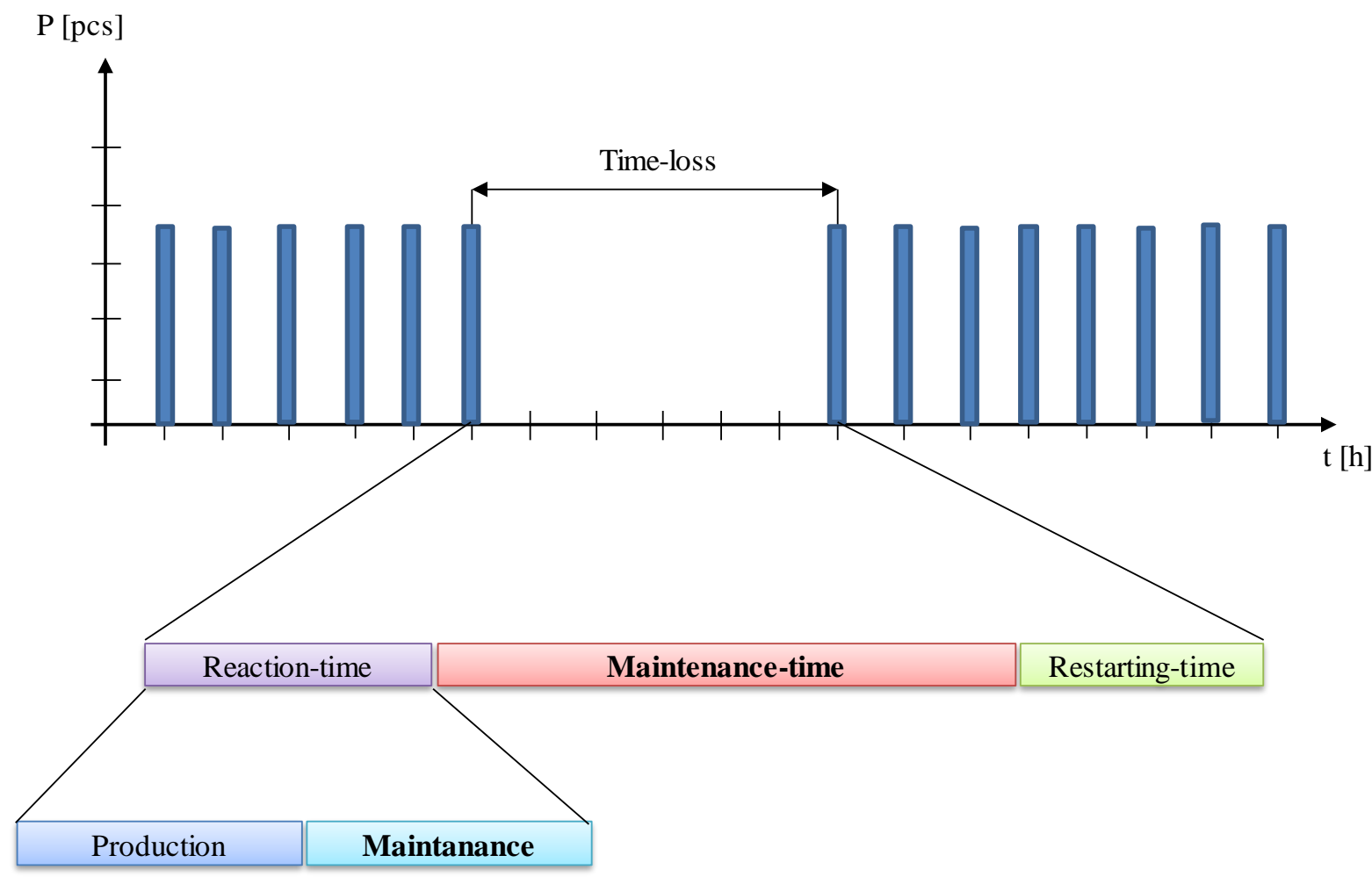

Fig. 2 Time components of the maintenance

If we describe the time-loss, it can be divided into three different components, which have not affect to each other:

- reaction time: the interval between the occurring of the maintenance requirement and the beginning of the activities, which can be further divided into manufacturing and maintenance reaction.

- maintenance time: time of the maintenance activities.

- restarting time: interval between the finished state of the machine and its restarting point.

The manufacturing reaction time and the restarting time is depending on the production process and the machine, it cannot be influenced by the maintenance process.

Total time of the maintenance contains the maintenance-time, maintenance reaction-time and the activities after finishing the maintenance (Fig. 3).

Elements of the maintenance reaction-time:

- time of the information-flow about the maintenance needs,

- preparation times of the operators,

- times of the previous activities (transport of devices, elements and operators),

- other preparation activities (e. g. measuring). 
Post activities related to a maintenance task:

- taking of non-used elements, devices and operators back,

- transfer of operators and devices to new maintenance locations,

- waste handling (transport, storing, treatment, etc.),

- activities in the stores (storing, crapping or reparation of the damaged devices, etc.).

Most of the post activities related to a maintenance process are the transportation back to the stores (devices and elements) and to waiting locations (operators). These activities do not have direct effects to the maintenance time, only some efficiency parameters can be influenced (device capacities absorbing).

The maintenance-time also has different components, which cannot be separated and calculated exactly, because they depend on the actual maintenance task and the applied strategy.

Main activity types of time components during the maintenance:

- supplying the elements - supplying-times,

- disassembling and assembling the machines - assembling-times,

- repairing the elements - reparation-times,

- verifying the operation of the finished machines - verifying-times, etc.

Total time of the maintenance

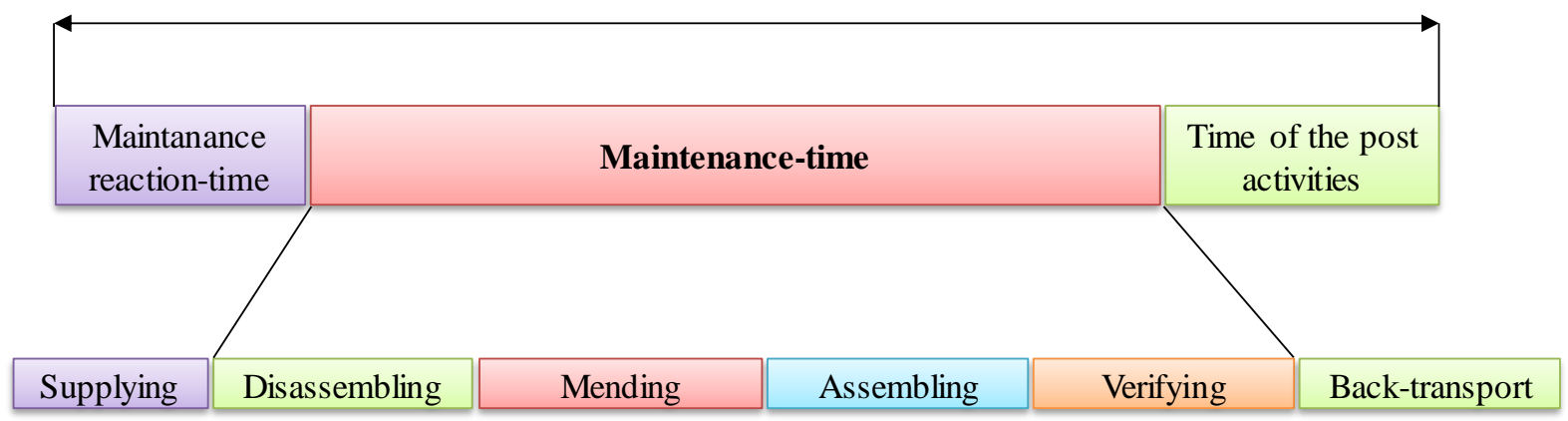

Fig. 3 Components of the maintenance time

\section{EFFECTS OF THE LOGISTIC PROCESS ON THE MAINTENANCE TIME}

There are many parameters to evaluate the logistic performance of a maintenance process (9), which can be grouped into different categories, depending on the characteristics that they are influencing (Fig. 4).

Logistic time factors have direct relation to the maintenance time, but other logistic parameters can also influence the time components. Besides, different logistic activities have different effects on the maintenance process, e. g.

- element supply $\rightarrow$ lack of the elements can increase the time,

- storing $\rightarrow$ registry errors can cause supply problems,

- operator allocation $\rightarrow$ wrong allocation can delay the maintenance process,

- transportation tasks $\rightarrow$ machine allocation mistakes can increase the process time, etc.

Of course, the best device to affect the time components of the maintenance is reducing the time requirement of logistic activities, where the time factors of the logistics (10) are

- ordering periods,

- order arrival times,

- storing cycles,

- transportation times, 
- handling times,

- waiting times, etc.

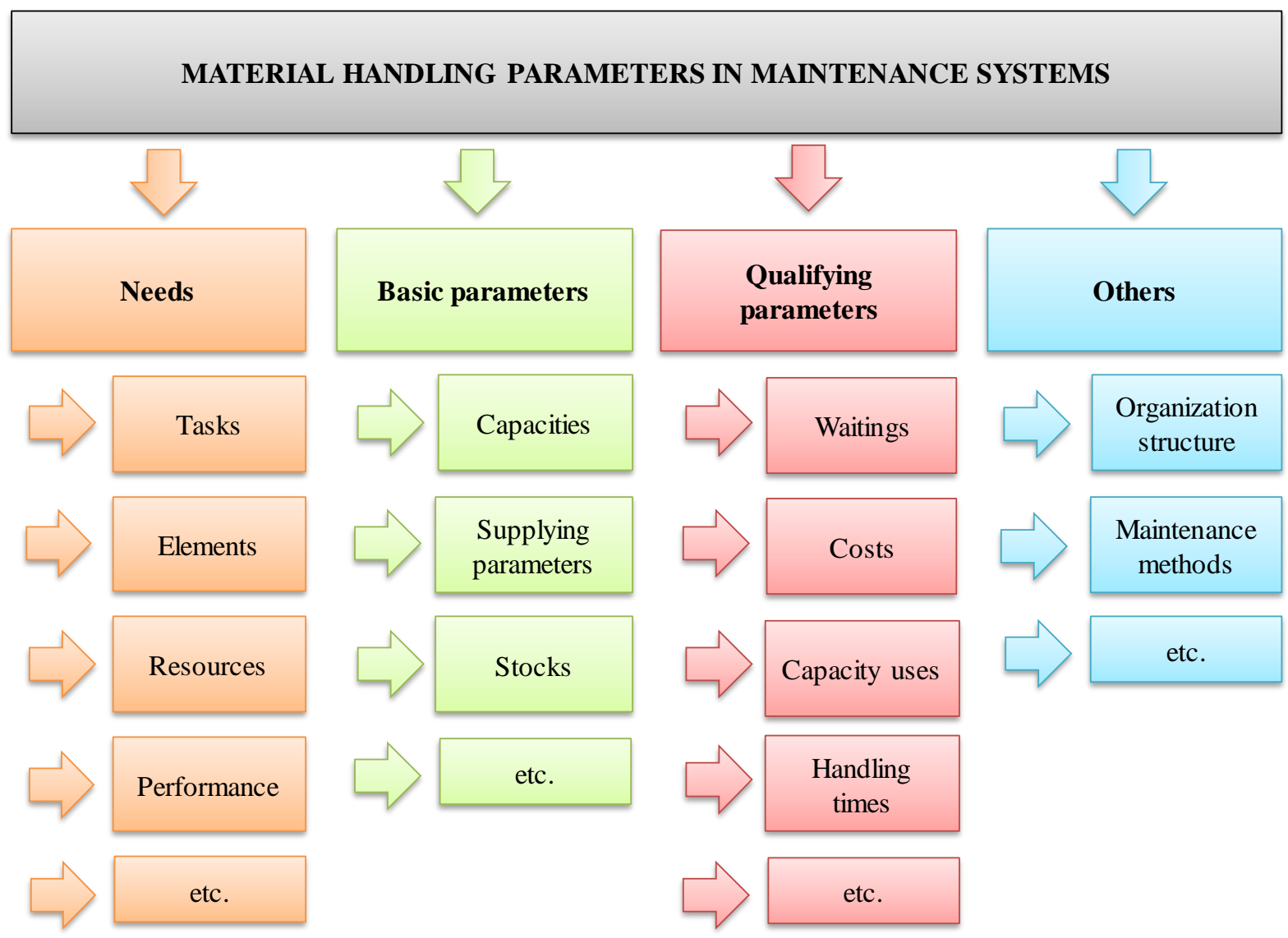

Fig. 4 Logistic parameters of the maintenance processes

Time factors of the maintenance logistics have effects on each other, but their relations usually are not direct. The largest difference exists between the maintenance process related (supplying, repairing transport and back transport) and the task-independent activities (order, order arrival and storing (11)). Their relation can be demonstrated by an example presented in Fig. 5.

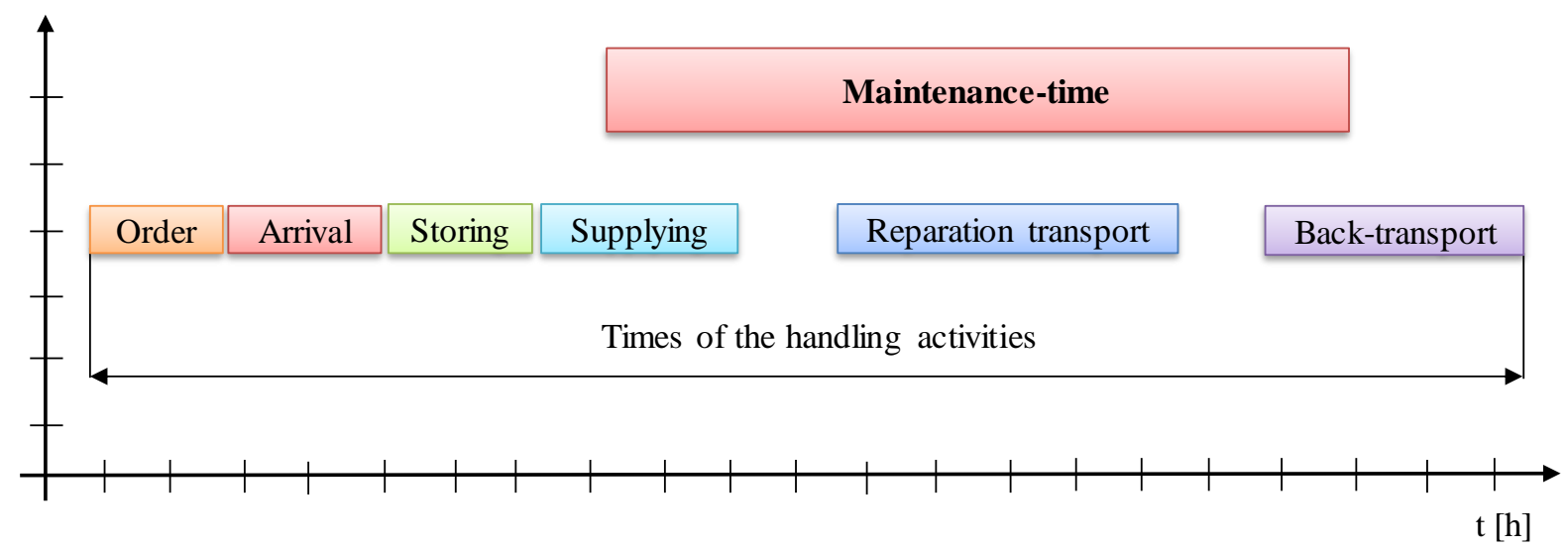

Fig. 5 Example for the logistic activities of a maintenance process

One of the most important logistic activities of the maintenance process is the supplying, in which elements, devices and operators required by the maintenance process are transported 
to a given location. These activities can be performed along different supplying strategies (Fig. 6), which can be:

A. Single supplying cycle: all the elements, devices and operators are transported together to the maintenance location before the beginning of the maintenance activities.

B. Multiple supplying cycles: the elements, devices and operators are transported in several phase to the maintenance location in

1) multiple previous transport: where all the transport phases are performed before the beginning of the maintenance activities,

2) multiple previous and delayed transport: where some of the transport phases are performed before and some of them after the beginning of the maintenance activities.

Causes of the differences between the different strategies can be

- size differences of the elements or devices,

- large quantities of the required elements,

- capacity limits of the handling machines,

- availability of the operators or devices, etc.

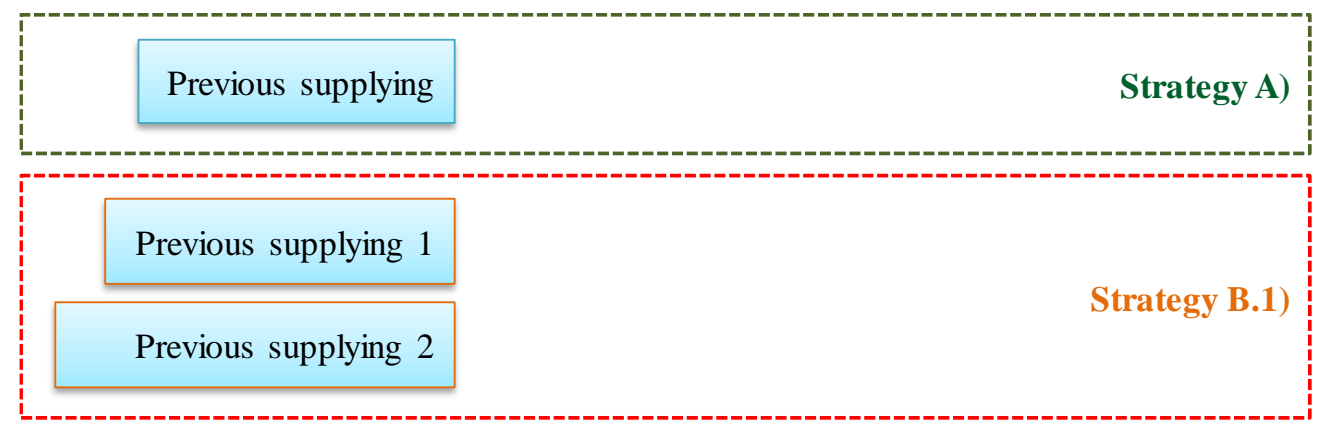

Maintenance-time

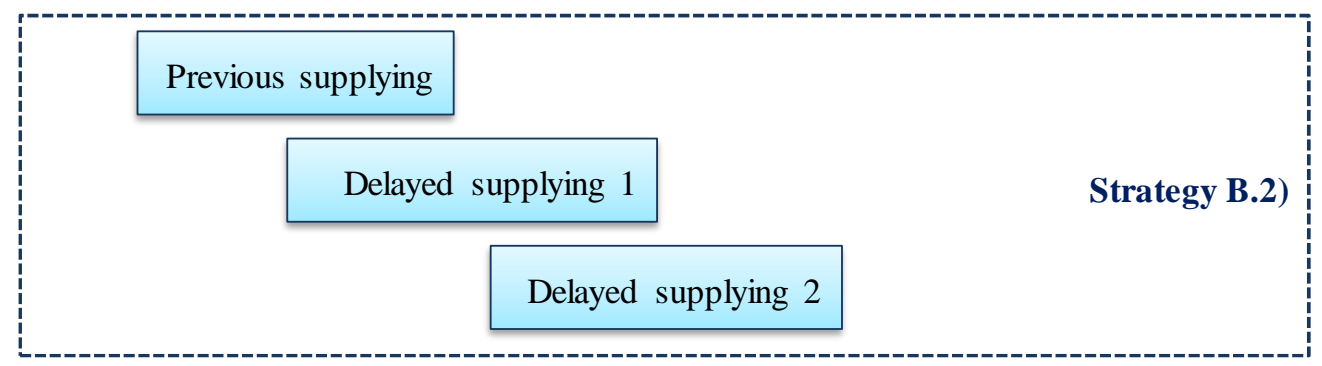

Fig. 6 Demonstration of the supplying strategies

Different supplying strategies have different effects to the maintenance time. If all the supplying phases are performed before the beginning of the maintenance activities (strategy A and B1), the supplying times do not have direct influence on the maintenance time; they can only affect the maintenance reaction-time.

In case of multiple previous and delayed transport (B2), the scheduling of the delayed transport cycles can modify the maintenance time, because the maintenance activities need the transported elements, devices and operators. 
There can be different waiting events during the maintenance process, which have direct influence on the maintenance time, usually increase it. Most important waiting types of the logistic activities can be

- waiting of the maintenance activities for an element or device,

- waiting of the handling machine,

- waiting of the repaired equipment, etc.

In certain cases, some effects of the waiting times cannot appear, because they are in passive state of the whole process or some elements.

If any waiting increases the maintenance time, it reduces the efficiency of the process, so an important objective of the maintenance logistics is to eliminate the waiting elements; however, it is a hard task to reach it mainly in the case of complex systems.

\section{CONCLUSIONS}

Following the changes and the development in the field of the maintenance, we need many new concepts, methods and ideas to make effective handling processes.

Main objective of our research was to uncover the relations between the effectivity of the maintenance processes and the material handling activities. Analysing the maintenance systems and their handling requirements can help us to determine the most important factors and their influencing possibilities.

In this paper, we summarised the development of the maintenance processes, the actual handling tasks and described the time-elements of the maintenance process. Besides, we also presented the time-factors of the handling processes and described their effects to the maintenance-time.

If we can find the exact methods to determine the relations between the maintenance-time and the influencing logistic-times, we can increase the efficiency of the maintenance processes. Future steps of our research activities will be the searching for solutions, which can help to reduce the negative time-consequences of the handling processes.

\section{Acknowledgements}

This project received funding from the European Union's Horizon 2020 research and innovation programme under the Grant Agreement No. 691942. This research was partially carried out within the framework of the Centre of Excellence of Mechatronics and Logistics at the University of Miskolc.

\section{References:}

1. EICHLER, C. 1982. A karbantartás tervezése (Maintenance planning). Müszaki Könyvkiadó, Budapest ISBN 96310429228.

2. PÉCZELY, Cs. 2009. A karbantartás-menedzsment korszerü irányzatai és módszerei (Advanced directions and methods of the maintenance management). Magyar Grafika 2009/5. http://www.nyomdaiparikarbantartas.hu/publikaciok/download/karbantartasmenedzsment_i_es_m.pdf

3. KOVÁCS, Gy., CSELÉNYI, J., SOMOGYVÁRI, Zs. 2007. Method and conception for formation of a microregional virtual logistics network (in Hungarian). Conference proceedings: OGÉT 2007, XV. International Engineering Conference, Cluj-Napoca, Romania, pp. 216-221.

4. CSELÉNYI J., ILLÉS B. (eds.) 2006. Anyagáramlási rendszerek tervezése és irányitása I. (Design and control of material flow systems I), Miskolci Egyetemi Kiadó. 
5. CSELÉNYI J., ILLÉS B. (eds.) 2004. Logisztikai rendszerek I. (Logistic systems I), Miskolci Egyetemi Kiadó.

6. TEN HOMPEL, M., SCHMIDT, T., NAGEL, L. (Eds.). 2007. Materialflusssysteme. Förder- und Lagertechnik. Berlin: Springer.

7. TELEK, P. 2014. Korszerü karbantartási folyamatok logisztikai feladatai (Logistic tasks of advanced maintenance processes). Logisztikai híradó XXIV/1. pp. 27-29.

8. KOTA, L. 2011. Optimisation of Large Scale Maintenance Networks with Evolutionary Programming. DAAAM International Scientific Book 2011 ISSN 1726-9687, pp. 495-512. doi: 10.2507/daaam.scibook.2011.40

9. APPLE, J. M. 1977. Material handling system design. John Wiley \& Sons, New York p. 656 ISBN 0471066524

10. ILLÉS, B. 2006. A karbantartási logisztika, a minőségbiztositási logisztika alapjai, folyamatának matematikai modellezése (Principles and mathematical modelling of the logistics of maintenance and quality management processes). Habilitáció, ME Gépészmérnöki Kar. Miskolc

11. CSELÉNYI, J., SMID, L., KOVÁCS, Gy., (2002). Evaluation methods of storage capacity between manufacturing levels at changing product structure. Conference proceedings: MicroCAD 2002, International Scientific Conference, Miskolc, Hungary, pp. 63-71. 